\title{
ANALYSIS OF THE IMPACT OF ANCHORING, HERDING BIAS, OVERCONFIDENCE AND ETHICAL CONSIDERATION TOWARDS INVESTMENT DECISION
}

\author{
Robin $^{1}$, Vanne Angelina ${ }^{2}$ \\ Faculty of Economics, Universitas Internasional Batam, Batam, Indonesia \\ Email: robin@uib.ac.id
}

\begin{abstract}
There are lots of factors that investors need to take in consideration before investing. Although the importance of external factors is undeniable, in recent decade, experts started to realize the importance of internal factors in investing. This includes behavior and psychological factors. This analysis of internal factor is what we refer to as behavior finance. However, just how important behavior finance is, and how significant it is in investment decision? In this study, researcher aims to determine the impact of anchoring, herding bias, overconfidence, and ethical consideration towards investment decision. Questionnaires were distributed to 149 investors of different backgrounds to determine the impact of behavior finance towards investment decision. PLS-SEM was used to test the research hypotheses. Through this research, it is determined that behavior and psychological biases and tendencies do affect investment decision. It is important to understand behaviors in investing because these behavior biases and tendencies can potentially lead to loss. Understanding behavior finance means investors can avoid behavior biases and rectify mistakes.
\end{abstract}

Keywords: anchoring, ethical consideration, herding bias, overconfidence, investment decision

\section{ARTICLE INFORMATIONS}

Article histiry: submitted: November 7, 2020; revised: December 14, 2020; accepted: December 22, 2020

JEL Classifiction: 016, R53

How to cited: Robin, R. and Angelina, V. (2020). Analysis of The Impact of Anchoring, Herding Bias, Overconfidence and Ethical Consideration Towards Investment Decision. JIMFE (Jurnal IImiah Manajemen Fakultas Ekonomi), 6(2), 253-264. https://doi.org/10.34203/jimfe.v6i2.2558

Copyright@2020. JIMFE (Jurnal Ilmiah Manajemen Fakultas Ekonomi) Universitas Pakuan

\section{INTRODUCTION}

Investing your money whether in stock, insurance, bonds, or other forms of investing requires a lot of consideration and analysis. Of course, when an investor decides to invest in something, they would aim for maximum profit and try to minimize the risk. However, investing is not merely theory and analysis. For an investor, there are a lot of determinant internal and external factors to take in consideration before making an investment. External factors may include the company's present performance, the company's growth, the company's past profit performance, future financial performance forecast, professional recommendation, and many more. While the external factors are important, internal factors sometimes become limitation or perpetuates error for investors before making investment decision. Psychological bias and tendencies often disrupt investors' thought process and intercepts rational thinking.

For the past three decades, when investing, we have always gone by two assumptions. With the assumption that investors only act for their best interest, the behavioral biases that comes with investing are often overlooked or even not acknowledged at all. However, as time goes by, it is evident that that is not the case. Over time, psychology and finance integrates with one another. This integration is what we refer to as behavioral finance.

Behavioral finance seeks to understand how emotional and cognitive errors affects the behavior of investors. The resulting biases and 
tendencies cause investors to act irrationally which influences their decision taking behavior. Behavioral finance comprises of two main categories, which are heuristics bias and cognitive bias. Heuristics bias includes representativeness, anchoring, and availability. Cognitive bias includes overconfidence, overreaction, and herding (Boda \& Sunitha, 2018). The existence of behavioral finance helps to provide explanation to the anomalies in investing and then provides the solution to help combat it.

The main problem in this study are examine the effect of anchoring, herding bias, overconfidence, and ethical consideration towards investment decision following Zhang and Zheng (2015), Amakobe (2016), Czerwonka (2017), and Pikulina et al. (2017). They argue those variables are effectively affect the investment decision. We focus on the variables that categories into psychological behavior. Furthermore, Wendy et al. 2014 argue that investor decision is relatively to irrational rather than rational.

Anchoring as defined by Czerwonka (2017) is a psychological behavior where an individual's judgment relies excessively on an opinion previously exposed to them. This means people tend to assess their decision making profoundly on an initial information exposed to them, in this case, investors tend to base their future investment decision on the initial price of the stock they purchased. Anchoring bias is also susceptible to change by cognitive ability, mood, financial literacy, experience, and personality. Investors with anchoring bias tendencies often base their value of their assets and future investment on their preceding information in regards of the buying price.

Investors are like a community. Active investors will check the news and portfolios daily. Herding, according to Zhang and Zheng (2015), is an irrational psychological behavior where an investor bases their opinion excessively on other people's opinion while disregarding their own. For example, when some investors sell their share, they follow through without proper analysis because they rely too much on majority's opinion without regarding their own situation and information. This behavioral bias happens because of our tendency as a human to believe the majority knows better.

Pikulina et al. (2017) defines overconfidence as a psychological behavior that differentiates a person's belief of their ability and knowledge versus their actual ability and knowledge. This behavioral phenomenon digs deep in overestimation. Investors with this tendency tends to overestimate their competence and underestimates the risk. What this means is some people tend to think the knowledge and ability they possess are greater than they actually are. When the stock they invest in goes up, the investors become too confident. They become certain they possess more knowledge and are more competent than others. Investors with this tendency also tend to underestimate risks there are because they believe they know better than others.

Ethics as defined by Amakobe (2016) deals with the values of human conduct. In specific, this means dealing with the rightness and wrongness of an action performed by in this case, business practices. According to (Dufford et al., 2018), this also includes motives and intention of the individual or group. Moral issues, especially in Indonesia as a country with a high moral conduct, is very important. It is very important for companies to comply with ethics and moral norms because it affects how the consumers perceive the company, which in turns affects sales and company performance.

As explained previously, behavioral finance, is very beneficial for investors because it helps investors to identify mistakes and rectify it. Ethical consideration has also becoming more substantial nowadays because people are starting to become conscious of sustainable living, especially in Riau Island. Researcher believes conscious lifestyle will slowly integrate with all aspects of life, hence, since this trend has only started in Riau Island 
in recent years, researcher is interested to see how the new conscious lifestyle will be integrated with the existing financial behavioral of investors in Riau Island, especially with the recent increase of interest in investing in Riau Island.

The purpose of this research is to analysis the effect of anchoring, herding bias, overconfidence, and ethical consideration towards investment decision. This research is benefits for (1) investors are able to gain better understanding regarding anchoring, herding, overconfidence, and ethical consideration's importance as a benchmark of eligibility in making investing decisions in a company in order to achieve identify common mistake and maximize profit. (2) This research can be used in order to spread awareness about behavioral finance which includes anchoring, herding, and overconfidence, also to raise awareness about the importance of ethical consideration and how all of the variables affect investment decision (Zhang and Zheng, (2015); Amakobe, (2016); Czerwonka (2017); Pikulina et al., (2017).

\section{LITERATURE REVIEW AND RESEARCH DEVELOPMENT}

\section{Relationship Between Anchoring and} Investment Decision

In their how behavior factors affects investment decision, Donkor et al. (2016) found anchoring positively affects investment decision. In their study, they found $82 \%$ of their respondents reported how past performance affects their current investment decision. They also found anchoring along with overconfidence to be the most dominant factors which affects investment decision. They found positive significance between past performance and investment decision because the respondents of their study retain past performance portfolio as an anticipation in their present investments to acquire better returns. They also found how the respondents of their study are unlikely to alter their opinion once its formed unless the most recent relevant information comes to light.

Mahalakshmi and Anuradha (2018) researched how behavioral biases, level of engagement, and spouse effect affects investment decision. They found low significance between anchoring and investment decision. This is based on the fact that although internal factor such as anchoring can affect investment decision, it is not as significant as other factors. They found a handful of external factors that affect investment decision more, such as marital status. This is based on the fact that investors who are married are less likely to rely on previous information they have and follow the flow of the market more because they would strive to minimize risk.

Previous studies were done to test the relationship between anchoring and investment decision. A lot of the studies found positive significant relationship between anchoring and investment decision. This finding is supported by Donkor et al. (2016), Khan et al. (2017), Gitau et al. (2018), Sochi (2018), Parveen and Siddiquee (2018), and Madaan and Singh (2019).

$H_{1}$ : There is a significant relationship between anchoring and investment decision.

Relationship Between Herding Bias and Investment Decision

Ghalandari and Ghahremanpour (2013) in their research found herding bias positively affects investment decision in Tehran Stock Market. They found Tehran Stock Market does not provide enough information for investors and how Tehran Market Stock is not mature yet, hence why investors in Iran tend to follow the majority decision as they do not have reliable source of information. Through this study they found investors who are affected by herding bias believe following majority decision increases the chance of better return and reduces risks. 
Previous studies were done to test the relationship between herding bias and investment decision. A lot of the studies found positive significant relationship between herding bias and investment decision. This finding is supported by Kengatharan and Kengatharan (2014), Mahanthe and Sugathadasa (2018), Pahlevi and Oktaviani (2018), Sochi (2018), and Qasim et al. (2019).

$\mathrm{H}_{2}$ : There is a significant relationship between overconfidence and investment decision.

\section{Relationship Between Overconfidence and Investment Decision}

Qadri and Shabbir (2014) in their illusion of control analysis towards investment decision found that overconfidence creates this illusion of control. They found that investors with this tendency trades aggressively because they overestimate their own competence and make decision based on the illusion they know a lot more than other people. This is triggered by past returns. They found high positive significance between overconfidence and investment decision. The coefficients in this study shows psychological bias like overconfidence positively impacts decision making in investing. Overconfident investors trade more rapidly and disregards technical analysis before investing. Interestingly, in this study they also found male investors are more overconfident than female investors. However, no further explanation was given on why male investors tend to be more overconfident than female investors.

Previous studies were done to test the relationship between overconfidence and investment decision. A lot of the studies found positive significant relationship between overconfidence and investment decision. This finding is supported by Gitau et al. (2018), Qasim et al. (2019), Mahanthe and Sugathadasa (2018), Areiqat et al. (2019), and Raut and Kumar (2018).

$\mathrm{H}_{3}$ : There is a significant relationship herding bias and investment decision.
Relationship Between Ethical Consideration and Investment Decision

Huang et al. (2016) found the participants of their study shows higher tendency to invest in ethically compliant companies. They found positive significant relationship between perceived moral intensity and remedial measures with investment decision. They found perceived moral intensity affects ethical investment consideration. This means participants of this study are more likely to invest in companies that are in line with their moral norm. They believe strengthening investors' perceived moral intensity encourages investors to invest ethically.

Previous studies were done to test the relationship between overconfidence and investment decision. A lot of the studies found positive significant relationship between overconfidence and investment decision. This finding is supported by Kim and Rasiah (2011), Rubaltelli et al. (2015), Von Wallis and Klein (2015), and Rossi et al. (2016).

$\mathrm{H}_{4}$ : There is a significant relationship between ethical consideration and investment decision.

\section{RESEARCH METHOD}

\section{Research Design}

This research uses quantitative method. Quantitative method is used in a research to test, analyse, and confirm hypotheses (Palinkas et al., 2015). The data collected for this research was spread in the span of five months, from December 2019 to April 2020. 149 questionnaires have spread to object of the research and 149 questionnaires came back.

Anchoring, Herding Bias, Overconfidence, and Ethical Consideration are the independent variables for this research, with Investment Decision as the dependent variable. We chose this as the research topic as we have noticed the growing trend of ethically compliant business practice and rights movements all around the world. We also believe behavioural biases affects the investment decision making due to overwhelming studies published about 
it and how investors often neglect the internal factors when investing and only focusing on the external factors without realizing the importance of behavioural biases and how it interfere with rational decision making process. Based on Ajayi (2017), primary data refers to real time data obtained through questionnaires, observations, surveys, and interview where respondents provide researcher data that is unique to individuals, but still relevant to the research. Primary data is useful for this particular research because the data obtained are up-to-date and reflects to current lifestyle and investing behavior.

\section{Sample and Data}

Samples were taken based on non-probability sampling techniques, specifically purposive sampling. Purposive sampling is designed to produce data that focuses on people with similar traits useful specifically for the research (Etikan, 2016). Specifically, homogenous sampling technique was used. Homogenous sampling refers to samples that share similar characteristics for a particular field of study. The samples used for this research are people who have invested in any form of investment. The decision to use purposive sampling is the researcher believes this technique is the best in order to provide the most relevant information to the research, which is about investment decision. According to Hair et al. (2011), the minimum sample required is 1:5. An investment decision include 5 questions refers to (Qadri and Shabbir, 2014), anchoring include 5 questions refers to (Czerwonka, 2017), herding bias include 4 questions refers to (Zhang and Zheng, 2015), overconfidence include 4 questions refers to (Pikulina et al., 2017). and ethical consideration include 4 questions refers to (Amakobe, 2016).

\section{Data Analysis Method}

Data analysis is defined as a method where data is collected, then processed with statistics which then is used to answer the formulation of the problem in the study. Research instruments are tools that can be used to obtain, process, and interpret information obtained by researchers using the same measurement pattern. Data collection in a study can be in the form of a questionnaire, so that the instrument measurement scale determines the units obtained, as well as data types or data levels (data of nominal, ordinal, interval and ratio types).

In this research, methods used include simple linear regression and multiple correlation. Researcher will then use SmartPLS to process the data obtained through questionnaire. Regression analysis refers to the statistical analysis where relationship between two quantitative variables are measured. This analysis aims to estimate or predict the average value of the dependent variable based on the value of the known independent variable.

\section{RESULT AND DISCUSSION}

\section{Respondents' demography analysis}

The data collected was obtained by various sources, mainly by gender, age, education, occupation, income, and investment. This was done with the reason of obtaining wide range of data that will contribute to this research and produce data that is true from real people with different backgrounds, but is still relevant towards the purpose of this research. By gender category, 81 are male respondents and the rest 68 are female respondents. By age category, the biggest group are between 18-25 years old respondents. By education, the biggest group of this data comprises of people that graduated SMA/SMK/Equivalent. In terms of occupation, students are the biggest group in this questionnaire. In income segment, the biggest group is comprised of people with Rp3.000.001-Rp5.000.000 income. Lastly, for form of investment, the most popular form of investment for respondents in this study is stock. 
Table 1. Respondents' Demography

\begin{tabular}{|c|c|c|}
\hline Categories & $\begin{array}{c}\text { Number of } \\
\text { Respondents }\end{array}$ & Percentage \\
\hline \multicolumn{3}{|l|}{ Gender } \\
\hline Male & 81 & $54,36 \%$ \\
\hline Female & 68 & $45,64 \%$ \\
\hline \multicolumn{3}{|l|}{ Age } \\
\hline$\leq 17$ & 2 & $1,34 \%$ \\
\hline $18-25$ & 59 & $39,59 \%$ \\
\hline $26-30$ & 23 & $15,44 \%$ \\
\hline $31-35$ & 37 & $24,83 \%$ \\
\hline $36-40$ & 14 & $9,4 \%$ \\
\hline$\geq 41$ & 14 & $9,4 \%$ \\
\hline \multicolumn{3}{|l|}{ Education } \\
\hline $\begin{array}{l}\text { SMA/SMK/ } \\
\text { Equivalent }\end{array}$ & 78 & $52,34 \%$ \\
\hline Diploma & 1 & $0,68 \%$ \\
\hline $\begin{array}{l}\text { Bachelor's } \\
\text { Degree }\end{array}$ & 66 & $44,3 \%$ \\
\hline $\begin{array}{l}\text { Master's } \\
\text { Degree }\end{array}$ & 4 & $2,68 \%$ \\
\hline \multicolumn{3}{|l|}{ Occupation } \\
\hline Students & 61 & $40,9 \%$ \\
\hline Businessmen & 49 & $32,9 \%$ \\
\hline $\begin{array}{l}\text { Marketing/ } \\
\text { Sales }\end{array}$ & 8 & $5,4 \%$ \\
\hline Office Worker & 14 & $9,4 \%$ \\
\hline Banker & 17 & $11,4 \%$ \\
\hline \multicolumn{3}{|l|}{ Income } \\
\hline$\leq \mathrm{Rp} 3.000 .000$ & 12 & $8,05 \%$ \\
\hline $\begin{array}{l}\text { Rp3.000.001 - } \\
5.000 .000\end{array}$ & 72 & $48,33 \%$ \\
\hline $\begin{array}{l}\text { Rp5.000.001 - } \\
10.000 .000\end{array}$ & 14 & $9,4 \%$ \\
\hline $\begin{array}{l}\text { Rp10.000.001 } \\
-15.000 .000\end{array}$ & 38 & $25,5 \%$ \\
\hline $\begin{array}{l}\geq \\
\text { Rp15.000.001 }\end{array}$ & 13 & $8,72 \%$ \\
\hline \multicolumn{3}{|l|}{ Investment } \\
\hline Stock & 48 & $32,2 \%$ \\
\hline Gold & 4 & $2,7 \%$ \\
\hline Property & 20 & $13,43 \%$ \\
\hline Obligation & 15 & $10,07 \%$ \\
\hline Deposits & 41 & $27,51 \%$ \\
\hline Mutual Funds & 21 & $14,09 \%$ \\
\hline
\end{tabular}

\section{Common Method Bias Analysis}

Common method bias is a phenomenon that happens when respondents of a research is influenced by the questionnaire given for the purpose of the study, hence creating common variation that affects the result of the study. To test whether or not the data of this research is affected by common method bias, an analysis using SPSS program will be conducted, specifically Harman's one factor, or commonly known as single factor test. A factor is considered to be biased if the value of percentage of variance is above $50 \%$ (Kock, 2015). From the table 2 , we can conclude that the percentage of variance is $21,711 \%$, which means its less than half of $50 \%$. This indicates that the factor is not affected by common method bias, and therefore the results will not be affected.

Table 2. Common Method Bias (CMB)

\begin{tabular}{cccc}
\hline Variable & Total & $\begin{array}{c}\text { \% of } \\
\text { Variance }\end{array}$ & Cumulative \% \\
\hline $\begin{array}{c}\text { Investment } \\
\text { Decision }\end{array}$ & 4,125 & 21,711 & 21,711 \\
\hline
\end{tabular}

\section{Validity analysis}

Validity test for reflective indicator can be done by finding the correlation of indicator score and the construct score. Measurement with reflective indicator indicates changes that are present in an indicator in a construct if the other indicator in the same construct changes.

Table 3. Convergent Validity Analysis

\begin{tabular}{lcc}
\hline \multicolumn{1}{c}{ Variable } & Sample Mean & Validity \\
\hline Anchoring & 0,587 & Valid \\
\hline Herding Bias & 0,604 & Valid \\
\hline Overconfidence & 0,671 & Valid \\
\hline Ethical & 0,526 & Valid \\
Consideration & & \\
\hline
\end{tabular}

Appropriate Average Variance Extracted (AVE) analysis is needed to determine the discriminant validity. Average Variance Extracted (AVE) is needed to measure the variance of the construct (Zait and Bertea, 
2011). Fornell and Lacker (1981) determined the value of Average Variance Extracted (AVE) should at least be 0,5 to be considered valid.

Table 4. Discriminant Validity Analysis

\begin{tabular}{lcc}
\hline \multicolumn{1}{c}{ Variable } & AVE & Validity \\
\hline Anchoring & 0,657 & Valid \\
\hline Herding Bias & 0,614 & Valid \\
\hline Overconfidence & 0,597 & Valid \\
\hline $\begin{array}{l}\text { Ethical } \\
\text { Consideration }\end{array}$ & 0,571 & Valid \\
\hline $\begin{array}{l}\text { Investment } \\
\text { Decision }\end{array}$ & 0,717 & Valid \\
\hline
\end{tabular}

\section{Composite Reliability Analysis}

Composite Reliability is a part, which examines the reliability value of variables present in the research. A variable can be concluded as reliable when the number of composite reliability is $>0,6$, which means if the number is $<0,6$ the variable has low reliability. If the number of composite reliability is $0,7-0,9$, it means the variable has a high reliability and with $>0,9$ means the reliability is perfect.

Table 5. Reliability Analysis Result

\begin{tabular}{lcc}
\hline \multicolumn{1}{c}{ Variable } & $\begin{array}{c}\text { Composite } \\
\text { Reliability }\end{array}$ & Reliability \\
\hline Anchoring & 0,653 & Reliable \\
\hline Herding Bias & 0,730 & Reliable \\
\hline Overconfidence & 0,727 & Reliable \\
\hline $\begin{array}{l}\text { Ethical } \\
\text { Consideration }\end{array}$ & 0,773 & Reliable \\
\hline $\begin{array}{l}\text { Investment } \\
\text { Decision }\end{array}$ & 0,831 & Reliable \\
\hline
\end{tabular}

Reliability analysis can be determined through the value of sample mean of Cronbach Alpha. Based on Table 6, the sample mean values of all variables are above 0,7 , which means the data is reliable.
Table 6. Cronbach's Alpha Analysis

\begin{tabular}{lcc}
\hline \multicolumn{1}{c}{ Variable } & $\begin{array}{c}\text { Cronbach } \\
\text { Alpha }\end{array}$ & Reliability \\
\hline Anchoring & 0,925 & Reliable \\
Herding Bias & 0,891 & Reliable \\
Overconfidence & 0,917 & Reliable \\
Ethical & 0,824 & Reliable \\
$\begin{array}{l}\text { Consideration } \\
\text { Investment }\end{array}$ & 0,902 & Reliable \\
Decision & & \\
\hline
\end{tabular}

\section{t-test}

In statistical analysis, t-test is also known as partial test, is a statistical hypothesis test where independent variables are analyzed individually regarding their relations with the dependent variable. To get the value of t-test, path coefficient result of bootstrapping is analyzed. Relationship between variables is considered to have significant relationship if the value of $t$-statistics is more than 1,96 or if the $p$-value is less than 0,05 (Hair et al., 2011).

Table 7. Bootstrapping Analysis

\begin{tabular}{lccc}
\hline $\begin{array}{c}\text { Independent } \\
\text { Variables }\end{array}$ & $\mathbf{B}$ & $\begin{array}{c}\mathbf{t}- \\
\text { statistics }\end{array}$ & $\begin{array}{c}\mathbf{p}- \\
\text { value }\end{array}$ \\
\hline Anchoring & 0,259 & 6,640 & 0,000 \\
Herding Bias & 0,332 & 8,211 & 0,000 \\
Overconfidence & 0,272 & 6,632 & 0,000 \\
Ethical & 0,412 & 8,316 & 0,000 \\
Consideration & & & \\
\hline
\end{tabular}

\section{$H_{1}$ : There is a significant relationship between anchoring with investment decision.}

Based on the result of the data processed, the value of beta for the variable anchoring is 0,259 and the $p$-value is 0,000 . This indicates that anchoring has positive significant influence on investment decision. Since the demography of respondents of this research is varied and is not overpowered by any particular groups, it can be concluded that anchoring affects all types of investors. This finding is consistent with findings by Donkor et al. (2016), Khan et al. (2017), Gitau et al. (2018), 
Parveen and Siddiquee (2018), Sochi (2018), and Madaan and Singh (2019).

Anchoring affects investors because in times of uncertainty and when there is lack of information for investors to decide or go forward, using the information they already have give investors an idea of plausible range and an overview of what they should expect. When investors deem not enough information is provided and money is involved, it is natural for investors to compare their future investment endeavours with previous investments. In a sense, this gives them a sense of comfort and somewhat peace of mind because they have a rough outline of what they should expect and what to do moving forward (Czerwonka, 2017).

\section{$\mathrm{H}_{2}$ : There is a significant relationship between herding bias with investment decision.}

Based on the result of the data processed, the value of beta for the variable herding bias is 0,332 and the $p$-value is 0,000 . This indicates that herding bias has positive significant influence on investment decision. Since the demography of respondents of this research is varied and is not overpowered by any particular groups, it can be concluded that herding bias affects all types of investors. This finding is consistent with findings by Ghalandari and Ghahremanpour (2013), Kengatharan and Kengatharan (2014), Mahanthe and Sugathadasa (2018), Pahlevi and Oktaviani (2018), Sochi (2018), and Qasim et al. (2019).

There are a few of reasons why herding bias affects investors' investment decision making. Firstly, it is within our nature as a human to follow the herd because the mindset of "following the majority must be the right thing to do because since the majority is doing it, it must be the right" is ingrained within us. Secondly, it is a part of our natural instinct as human to follow the crowd. There is a social pressure that enforces everyone to conform to what the majority does. Lastly, lack of selfconfidence contributes to investors being affected by herding bias. This is because when investors think their expertise or knowledge is not good enough to make an investment decision, they should just follow the crowd because of this preconceived notion that the mass is unlikely to be wrong (Zhang and Zheng, 2015).

\section{$H_{3}$ : There is a significant relationship between overconfidence with investment decision.}

Based on the result of the data processed, the value of beta for the variable overconfidence is 0,272 and the $p$-value is 0,000 . This indicates that overconfidence has positive significant influence on investment decision. Since the demography of respondents of this research is varied and is not overpowered by any particular groups, it can be concluded that overconfidence affects all types of investors. This finding is consistent with findings byQadri and Shabbir (2014), Gitau et al. (2018), Mahanthe and Sugathadasa (2018), Raut and Kumar (2018), Areiqat et al. (2019), and Qasim et al. (2019).

Overconfident tendency happens when an investor overestimates their knowledge or expertise, and when an investor is too optimistic. In a lot of cases, overconfidence affects investors who have been in the market for a long period of time, or investors who made significant returns from their past investments. This makes sense because investors who have been trading for a long time or investors who made huge returns from their past investments tend to believe they get so far or earn so much because of their expertise as an investor. As human, we do naturally have the tendency of overestimating how good we are at something. The more overconfident the investor is, the more willing they are to take higher risks because they think they possess enough knowledge to do so (Pikulina et al., (2017). 


\section{$\mathrm{H}_{4}$ : There is a significant relationship between ethical consideration with investment decision.}

Based on the result of the data processed, the value of beta for the variable ethical consideration is 0,412 and the $p$-value is 0,000 . This indicates that ethical consideration has positive significant influence on investment decision. Since the demography of respondents of this research is varied and is not overpowered by any particular groups, it can be concluded that ethical consideration affects all types of investors. This finding is consistent with findings by Kim and Rasiah (2011), Rubaltelli et al. (2015), Von Wallis and Klein (2015), Rossi et al. (2016), andHuang et al. (2016).

As the society progresses to be more conscious, ethical consideration has become a new factor to consider before an investor decides to invest. In the old days, financial return used to be the only factor that is important in investment. Through this research, we can conclude how in this day and age, moral values are just as important as financial return. As the world develops and information becomes easily accessible, issues in the world that used to be unknown are now discussed all around the world in real time. This is especially true for younger investors, as younger people in general are actively taking into account societal issues like environment, human and animal rights, moral, race, worker rights, and many other factors in their daily life (Amakobe, 2016).

\section{CONCLUSION}

This research was done to determine the influence of anchoring, herding bias, overconfidence, and ethical consideration towards investment decision. This research aims to understand the point of view of investors better with the change of business norm. in this research, we find that anchoring, herding bias, overconfidence, and ethical consideration are positively and significantly on investment decision. Our research also support the previous studies (Qadri and Shabbor, 2014).

\section{REFERENCE}

Ajayi, V. O. (2017). Primary Sources of Data and Secondary Sources of Data. September, 16.

https://doi.org/10.13140/RG.2.2.24292.6 8481

Amakobe, D. F. (2016). BADM870-1603C-1Organizational Behavior and Management Colorado Technical University.

Areiqat, A. Y., et al. (2019). Impact of Behavioral Finance on Stock Investment Decisions; Applied Study on a Sample of Investors at Amman Stock Exchange. Academy of Accounting and Financial Studies Journal, 23(2), 1-17.

Boda, J. R. and Sunitha, G. (2018). Investor's Psychology in Investment Decision Making: A Behavioral Finance Approach. International Journal of Pure and Applied Mathematics, 119(7), 1253-1261. https://acadpubl.eu/jsi/2018-1197/articles/7b/39.pdf

Czerwonka, M. (2017). Anchoring and Overconfidence: The Influence of Culture and Cognitive Abilities. International Journal of Management and Economics, 53(3), 48-66. https://doi.org/10.1515/ijme-2017-0018

Donkor, J., et al. (2016). Behavior Factors and Investment Decisions of Bankers in Ghana. British Journal of Education, Society \&Behavior Science, 18(3), 1-8. https://doi.org/10.9734/bjesbs/2016/23 353

Dufford, W. E., et al. (2018). Justice and Fairness. My Tour through the Asylum, 156-160.

https://doi.org/10.2307/j.ctv6wgd0b.61

Etikan, I. (2016). Comparison of Convenience Sampling and Purposive Sampling. American Journal of Theoretical and 
Applied Statistics, 5(1), 1. https://doi.org/10.11648/j.ajtas.2016050 1.11

Fornell, G. and Lacker, R. N. (1981). Introduction to Linear Regression Analysis.

Ghalandari, K. and Ghahremanpour, J. (2013). The Effect of Market Variables and Herding Effect on Investment Decision as Factor Influencing Investment Performance in Iran. Journal of Basic and Applied Scientific Research, 3(3), 313-318.

Gitau, G. G., et al. (2018). Effect of Heuristic Factors and Real Estate Investment in Embu County, Kenya. International Journal of Academic Research in Accounting, Finance and Management Sciences, 8(4), 30-38. https://doi.org/10.6007/IJARAFMS/v8i4/5183

Hair, J. F., et al. (2011). PLS-SEM: Indeed a silver bullet. Journal of Marketing Theory and Practice, 19(2), 139-152. https://doi.org/10.2753/MTP10696679190202

Huang, C. Y., et al. (2016). Could the impaired intention of ethical investment be recovered? Journal of Management and Organization, 22(5), 736-750. https://doi.org/10.1017/jmo.2015.61

Kengatharan, L. and Kengatharan, N. (2014). The Influence of Behavioral Factors in Making Investment Decisions and Performance: Study on Investors of Colombo Stock Exchange, Sri Lanka. Asian Journal of Finance \& Accounting, 6(1), 1. https://doi.org/10.5296/ajfa.v6i1.4893

Khan, A. R., et al. (2017). Impact of Overconfidence and Loss Aversion Biases on Investment Decision: Moderating Role of Risk Perception. International Journal of Transformation in Accounting, Auditing, \& Taxation, 1(1), 1-12.

Khan, H. H., et al. (2017). Heuristics and stock buying decision: Evidence from Malaysian and Pakistani stock markets. Borsa Istanbul Review, 17(2), 97-110. https://doi.org/10.1016/j.bir.2016.12.00 2

Kim, P. K. and Rasiah, D. (2011). A study on ethical investment behaviour among Malaysian general insurance fund managers. Innovation and Knowledge Management: A Global Competitive Advantage - Proceedings of the 16th International Business Information Management Association Conference, IBIMA, $1, \quad 494506$. https://doi.org/10.5171/2011.1-62047

Kock, N. (2015). Common method bias in PLSSEM: A full collinearity assessment approach. International Journal of ECollaboration, 11(4), 1-10. https://doi.org/10.4018/ijec.2015100101

Madaan, G., and Singh, S. (2019). An Analysis of Behavioral Biases in Investment DecisionMaking. International Journal of Financial Research, 10(4), 55. https://doi.org/10.5430/ijfr.v10n4p55

Mahalakshmi, T. N. and Anuradha, N. (2018). Factors affecting Investment Decision making \& Investment Performance among Individual Investors in India. International Journal of Pure and Applied Mathematics, 118(18), 1667-1675.

Mahanthe, J. W. S. M. D. . and Sugathadasa, D. (2018). The Impact of Behavior Factors on Investment Decision Making in Colombo Stock Exchange. The International Jounal of Business \& Management, 6(8), 199207.

Pahlevi, R. W. and Oktaviani, I. I. (2018). Determinants of Individual Investor Behaviour in Stock Investment Decisions. AFRE Accounting and Financial Review, 1(2), 53-61. https://doi.org/10.26905/afr.v1i2.2427

Palinkas, L. A., et al. (2015). Purposeful Sampling for Qualitative Data Collection and Analysis in Mixed Method Implementation Research. Administration and Policy in Mental Health and Mental Health Services Research, 42(5), 533-544. https://doi.org/10.1007/s10488-013- 
JIMFE (Jurnal Ilmiah Manajemen Fakultas Ekonomi)

https://journal.unpak.ac.id/index.php/jimfe

0528-y

Parveen, S. and Siddiquee, M. (2018). Anchoring Heuristic, Disposition Effect and Overconfidence Bias in Investors: A Case of Pakistan Stock Exchange. Abasyn Journal of Social Sciences, 11(2), 280-294.

Pikulina, E., et al. (2017). Overconfidence and investment: An experimental approach. Journal of Corporate Finance, 43, 175192.

https://doi.org/10.1016/j.jcorpfin.2017.0 1.002

Qadri, S. U. and Shabbir, M. (2014). An Empirical Study of Overconfidence and Illusion of Control Biases, Impact on Investor's Decision Making: An Evidence from. European Journal of Business and Management, 6(14), 38-45.

Qasim, M., et al. (2019). Impact of Herding Behavior and Overconfidence Bias on Investors' Decision-making in Pakistan. Accounting 5, 81-90. https://doi.org/10.5267/j.ac.2018.07.001

Raut, R. K. and Kumar, R. (2018). Investment Decision-Making Process between Different Groups of Investors: A Study of Indian Stock Market. Asia-Pacific Journal of Management Research and Innovation, 14(1-2), 39-49. https://doi.org/10.1177/2319510x18813 770.

Rossi, M., et al. (2016). Estimating the demand for new social investments in the
Vol. 6 No. 2, Des 2020, Hal. 253-264 P-ISSN: 2502-1400, E-ISSN: 2502-5678

Netherlands. Netspar Paper (048).

Rubaltelli, E., et al. (2015). Moral Investing: Psychological Motivations and Implications. Judgment and Decision Making, 10(1), 64-75.

Sochi, M. H. (2018). Behavioral Factors Influencing Investment Decision of the Retail Investors of Dhaka Stock Exchange : An Empirical Study. The Cost and Management, 46(1), 20-29.

Von Wallis, M. and Klein, C. (2015). Ethical requirement and financial interest: a literature review on socially responsible investing. Business Research, 8(1), 61-98. https://doi.org/10.1007/s40685-0140015-7

Wendy, W., et al. (2014). The Formation of Rational and Irrational Behaviors in Risky Investment Decision Making: Laboratory Experiment of Coping Theory Implication in Investors' Adaptation Model. Indonesian Capital Market Review, 4(2).

Zait, A. and Bertea, P. E. (2011). Methods for testing discriminant validity. Management and Marketing Journal 9(2). 217-224.

Zhang, Y. and Zheng, X. (2015). A Study of the Investment Behavior Based on Behavioral Finance. European Journal of Business and Economics, 10(1). https://doi.org/10.12955/ejbe.v10i1.55. 
